\title{
Detection of Leptospira spp. in wild Phrynops geoffroanus (Geoffroy's side-necked turtle) in urban environment
}

\author{
J.P. Oliveira, A.E. Kawanami, A.S.L. Silva ${ }^{1}$, D.G. Chung, K. Werther* \\ Departamento de Patologia Veterinária, Faculdade de Ciências Agrárias e Veterinárias (FCAV), Universidade Estadual Paulista (Unesp), Via de Acesso \\ Professor Paulo Donato Castellane s/n, 14884-900, Jaboticabal, SP, Brazil
}

\section{A R T I C L E I N F O}

\section{Article history:}

Received 1 July 2016

Received in revised form 15 August 2016

Accepted 21 August 2016

Available online 26 August 2016

\section{Keywords:}

Leptospira

Reptile

Terrapin

Zoonosis

Public health

\begin{abstract}
A B S T R A C T
Leptospira spp., a zoonotic agent relevant for public health, occurs frequently in tropical regions. The aquatic environment represents a viable survival and transmission pathway. This study aimed to investigate the presence of anti-Leptospira spp. antibodies in Phrynops geoffroanus (Geoffroy's side-necked turtle) serum samples using the microagglutination test (MAT), and Leptospira spp. in gastric and cloacal lavage samples using the polymerase chain reaction (PCR) technique. Antibodies against nine different Leptospira spp. serovars were detected in $45.45 \%$ (30/66) of the serum samples. Specific amplification of Leptospira spp. genomic material (331 bp) was observed in $16.67 \%(11 / 66)$ of the samples. In conclusion, these freshwater testudines host Leptospira spp. and eliminate them. This situation may represent a risk to public health, especially to people who use urban streams for fishing and recreational activities. Additionally, we described some Leptospira spp. serovars, not yet reported in testudines, detected here in $P$. geoffroanus.
\end{abstract}

(c) 2016 Elsevier B.V. All rights reserved.

\section{Introduction}

Leptospira spp. is a waterborne zoonotic bacterium (Adler and Moctezuma, 2010) relevant for public health (Silva et al., 2012). It is distributed worldwide, and its occurrence is higher in tropical regions, mainly where there is high seasonal rainfall (Acha and Szyfres, 2001). Infection by Leptospira spp. in humans occurs through direct contact with infected animals or indirectly by contact with a contaminated environment (Adler and Moctezuma, 2010).

Many domestic and wild mammals have been found to be either natural reservoirs or accidental hosts for several serotypes of Leptospira spp. However, non-mammalian animals such as those belonging to the herpetofauna (Andrews et al., 1965; Jobbins and Alexander, 2015) may play a role as reservoir hosts when considering the epidemiology (Glosser et al., 1974), transmission and persistence of Leptospira spp. (Jobbins and Alexander, 2015).

\footnotetext{
* Corresponding author.

E-mail addresses: julepaulavet@hotmail.com (J.P. Oliveira), aline.kawanami@gmail.com (A.E. Kawanami), aslsilva@yahoo.com.br (A.S.L. Silva), dgchungbr@yahoo.com (D.G. Chung),werther@fcav.unesp.br (K. Werther).

1 Present address: Universidade Federal do Oeste do Pará (UFOPA), Instituto de Biodiversidade e Floresta (IBEF), Rua Vera Paz s/n, Bairro Salé, 68035-110, Santarém, PA, Brazil.
}

Detection of leptospiral antibodies by microscopic agglutination test (MAT) is considered the standard serological test for laboratory diagnosis of mammalian leptospirosis (OIE, 2016); however, owing to the high sensitivity of this method (Adler and Moctezuma, 2010), false-positive results are possible (Grimm et al., 2015), which suggests caution should be taken when MAT is the only diagnostic method used (Glosser et al., 1974). Evidence indicates that MAT is a valid tool for surveying leptospiral infection in reptiles by seroconversion after experimental infection (Abdulla and Karstad, 1962). Leptospira spp. has been serologically detected in captive testudines (Esteves et al., 2005; Silva et al., 2010) and in wild terrapins present in environments frequented by humans (Andrews et al., 1965; Glosser et al., 1974; Silva et al., 2009; Grimm et al., 2015). Another sensitive and reliable diagnostic method for the detection of Leptospira spp. is polymerase chain reaction (PCR) (Acha and Szyfres, 2001), which has been successfully applied in reptiles' samples (Biscola et al., 2011; Jobbins and Alexander, 2015; Mitchell et al., 2015).

Phrynops geoffroanus (Geoffroy's side-necked turtle), a native South American freshwater turtle, lives in lakes, rivers, and streams (Rueda-Almonacid et al., 2007) with calm water flow (Souza, 2004). $P$. geoffroanus has been adapting to inhabit urban rivers polluted with organic waste (Souza and Abe, 2000; Souza, 2004).

This environmental condition is observed in the urban stream Córrego Cerradinho in the city of Jaboticabal, São Paulo state, Brazil. 
In this region, there is high rainfall during the summer season, with a large volume of water (Borges et al., 2003) that eventually overflows. In addition, humans use the stream for fishing and recreational activities. Occasionally, when specimens of $P$. geoffroanus are accidentally fished, they are kept as pets or used as food.

The present study aimed to search for Leptospira spp. and antibodies against these bacteria in $P$. geoffroanus captured in an anthropic environment.

\section{Material and methods}

\subsection{Subjects, period, study area and ethics statement}

Phrynops geoffroanus (Geoffroy's side-necked turtle) specimens were captured using net poles, from February to May 2012, along $1,9 \mathrm{Km}$ of the urban stream section of Córrego Cerradinho (total length of $11 \mathrm{~km})$ in the city of Jaboticabal $\left(21^{\circ} 15^{\prime} 22^{\prime \prime} \mathrm{S}\right.$ and $\left.48^{\circ} 18^{\prime} 58^{\prime \prime} \mathrm{W}\right)$, São Paulo state, Brazil.

This search was performed in accordance to the regulations of University ethics committee for animal use (protocol no. 007842/11) and of the Brazilian government (protocol no. 284401).

\subsection{Leptospira microagglutination test: samples and protocol}

Blood samples were collected from the cervical vertebral venous plexus; serum was obtained and stored at $-20^{\circ} \mathrm{C}$ to perform serology by MAT (OIE, 2016).

Detection of anti-Leptospira spp. antibodies was performed using twenty-four serovars (Andamana, Australis, Autumnalis, Bataviae, Bratislava, Butembo, Canicola, Castellonis, Copenhageni, Cynopteri, Grippotyphosa, Hardjo, Hebdomadis, Icterohemorrhagiae, Javanica, Panama, Patoc, Pomona, Pyrogenes, Sentot, Shermani, Tarassovi, Whitcombi, and Wolffi). Sera are considered positive when agglutination is greater than or equal to $50 \%$ (Glosser et al., 1974; OIE, 2016). Sera that tested positive in the first dilution were re-examined after two-fold serial dilutions, up to a maximum dilution of $1: 2560$. The cut-off titer was $\geq 1: 20$ (Abdulla and Karstad, 1962).

When a serum sample reacted with more than one serovar, the highest titer was used as to define the serovar detected. Animals whose serum reacted with multiple serovars at the same titer levels were labeled as "multiple titer" (Grimm et al., 2015).

\subsection{Molecular diagnosis of Leptospira: samples and protocols}

The terrapins were manually restrained; individual gastric and cloacal content was collected by lavage using sterile cateter probes and sterile $0.9 \%$ sodium chloride $(\mathrm{NaCl})$ solution. Samples were fractioned into $2-\mathrm{mL}$ sterile plastic microtubes and stored at $-20^{\circ} \mathrm{C}$.

The DNA extraction followed the by Kuramae-Izioka (1997) protocol with modifications made to the extraction buffer, which was composed of $100 \mathrm{mM}$ Tris- $\mathrm{HCl}$ pH 8.0, $50 \mathrm{mM}$ EDTA pH 8.0, $20 \mathrm{mM}$ $\mathrm{NaCl}$, and $0.5 \%$ sodium dodecyl sulfate.

DNA samples were processed and subjected to PCR to amplify a fragment of $331 \mathrm{bp}$ from the Leptospira rrs (16S) gene to identify Leptospira spp. using primers Lep1 ( $5^{\prime}$ - GGC GGC GCG TCT TAA ACA TG - 3') and Lep2 (5' - TTC CCC CCA TTG AGC AAG ATT- 3') (Mérien et al., 1992). Positive DNA samples used as controls were kindly donated by the Laboratório de Diagnóstico de Brucelose e Leptospirose from Universidade Estadual Paulista (Unesp), Jaboticabal, São Paulo, Brazil.

PCR was performed using $1 \mathrm{x}$ PCR buffer $(20 \mathrm{mM}$ Tris- $\mathrm{HCl}$ $\mathrm{pH} 8.4 ; 50 \mathrm{mM} \mathrm{KCl}) ; 2.0 \mathrm{mM} \mathrm{MgCl}_{2} ; 0.2 \mathrm{mM}$ of each deoxynucleoside triphosphate (dNTP); 5 pmol of each primer; $1 \mathrm{U}$ Taq DNA polimerase (Fermentas, Thermo Fisher Scientific); $7.0 \mathrm{~mL}$ of genomic DNA; and sterile Milli-Q water to $20 \mu \mathrm{L}$. Amplification was performed in a thermal cycler (Applied Biosystems, Foster City, California, USA) programmed to perform one cycle at $94^{\circ} \mathrm{C}$ for $4 \mathrm{~min}$, 35 cycles at $94{ }^{\circ} \mathrm{C}$ for $1 \mathrm{~min}, 60^{\circ} \mathrm{C}$ for $1 \mathrm{~min}$, and $72^{\circ} \mathrm{C}$ for $1.5 \mathrm{~min}$, followed by a final extension at $72{ }^{\circ} \mathrm{C}$ for $10 \mathrm{~min}$. The amplicons were visualized by electrophoresis on a $1.0 \%$ agarose gel.

\subsection{Evaluation of MAT sensitivity and specificity}

MAT has been used as serological test for Leptospira spp. diagnostic (OIE, 2016) in testudines (Andrews et al., 1965; Esteves et al., 2005; Glosser et al., 1974; Silva et al., 2009, 2010; Grimm et al., 2015). In order to analyze the sensitivity and specificity of MAT in these study, PCR was used as the gold standard diagnostic technique.

\section{Results and discussion}

\subsection{Leptospira microagglutination test}

The occurrence of antileptospiral agglutinins detected in this study $(45.45 \%, 30 / 66)$ corroborates other studies performed in wildlife testudines. Studies performed in Emydoidea blandingii (Blanding's turtles) have found anti-Leptospira antibodies in $100 \%$ (34/34) (Mitchell et al., 2015) and 93.5\% (29/31) (Grimm et al., 2015) of the samples. In Trachemys dorbigny (Black-bellied Slider) and Phrynops hilarii (Hilaire's Side-necked Turtle), 27.5\% (11/40) of the animals were positive (Silva et al., 2009). Glosser et al. (1974) described that $91.7 \%(44 / 48)$ of the samples from Sternothaerus odoratus (Stinkpot turtle) and Trachemys scripta elegans (Red-eared Slider) were positive. Additionally, Andrews et al. (1965) reported 89.09\% (49/55) of T. scripta elegans and 22.22\% (2/9) of Chelydra serpentina (Snapping turtle) were positive for anti-Leptospira antibodies. The same authors observed anti-Leptospira antibodies in $34.61 \%(18 / 52)$ of the samples when working with tortoises (Terrapene carolina carolina - Eastern box turtle)(Andrews et al., 1965).

In the present study, antibodies against nine serovars $(37.5 \%$, 9/24) of Leptospira spp. were detected. The most-commonly detected serovar was Copenhageni, with a frequency of $15.15 \%$ (10/66). Wildlife terrapins from the USA (Glosser et al., 1974) and captive freshwater turtles from Slovenia (Lindtner-Knific et al., 2013) were also reactive for this serovar.

The second most common serovar identified in the current study was $L$. Pyrogenes with $10.61 \%$ (7/66), followed by $L$. Autumnalis with $4.54 \%$ (3/66). No reports have been found about these serovars in testudine samples. $L$. Patoc $(4.54 \%, 3 / 66)$, which was detected in our study, has also been found in wild aquatic testudines from the USA (Glosser et al., 1974), and in captive tortoises (Silva et al., 2010) and terrapins (Esteves et al., 2005) from Brazil.

We observed lower titers of antibodies reactive to $L$. Canicola, $L$. Andamana, L. Grippotyphosa, and L. Castellonis in P. geoffroanus, which were detected at a frequency of $1.51 \%$ (1/66) for each serovar. The Canicola serovar has been reported in wildlife tortoises from the USA (Andrews et al., 1965) and wild terrapins from Brazil (Silva et al., 2009); it has been found in captive testudines from Brazil (Silva et al., 2010) and Slovenia (Lindtner-Knific et al., 2013) as well. The Andamana serovar has been described in testudines from the USA (Glosser et al., 1974) and from Brazil (Esteves et al., 2005; Silva et al., 2010). L. Grippotyphosa has been detected in wild freshwater turtles from the USA (Grimm et al., 2015) and from Brazil (Silva et al., 2009) as well as in captive terrapins and tortoises from Slovenia (Lindtner-Knific et al., 2013). Reports on the presence of L. Castellonis in testudines was not found in the literature.

Additionally, we found that serum samples from some $P$. geoffroanus were reactive to more than one Leptospira spp. serovars at equal titers ("multiple titer") as observed for 
Pyrogenes/Copenhageni $(3.03 \%, 2 / 66$, with titer 1:60) and Pyrogenes/Icterohemorrhagiae $(1.51 \%, 1 / 66$, with titer $1: 80)$. Grimm et al. (2015) reported "multiple titer" specimens for serovars Icterohemorrhagiae/Canicola (16.13\%; 5/31) and Icterohemorrhagiae/Grippotyphosa/Canicola (3.23\%; 1/31) in E. blandingii.

The serum antibody titers in the present study ranged between $\geq 1: 20$ and $\leq 1: 1280$. The frequencies of these titers were $1: 20$ (20.0\%, 6/30), 1:40 (30.0\%, 9/30), 1:80 (23.33\%, 7/30), 1:160 (23.33\%, $7 / 30)$, and $1: 1280(3.33 \%, 1 / 30)$. Andrews et al. (1965) suggested that high antibody titers and high reactor rates, in aquatic turtles under natural conditions, may be consequent to continued long-term exposure to water-borne leptospires. After conducting experimental infection with Leptospira spp. serovar Pomona in freshwater turtles (E. blandingii and C. serpentina), Abdulla and Karstad (1962) observed the range of antibody titer peaks (1:20 to 1:60) and suggested that low environmental temperatures may interfere with the immune response and antibody production.

A screening dilution of 1:20 was used in the present work. Different titer cut-offs were used for serum samples obtained from terrapins in previous studies, such as 1:20 (Abdulla and Karstad, 1962), 1:25 (Grimm et al., 2015), 1:40 (Silva et al., 2010), 1:50 (Glosser et al., 1974; Lindtner-Knific et al., 2013), and 1:100 (:100 (Andrews et al., 1965; Esteves et al., 2005; Silva et al., 2009). Standard screening dilution for MAT in reptiles has not been established. Using low titer cut-offs such as 1:20 might result in low specificity and increased false-positive results. In order to limit factors that might lead to misinterpretation of results, such as cross-reaction among serovars at lower titers, the serovar with the highest titer should be considered positive (Grimm et al., 2015). For a better understanding of testudine's immune system and seroconversion, experimental infection and determination of a standard cut-off for MAT test would be indispensable.

Grimm et al. (2015) proposed that MAT results may confirm that a given leptospire has been present in the turtles' habitat, which characterizes exposure of reptiles to this bacterium, and represents an important first step in elucidating the epidemiology of this pathogen in terrapins. Serological methods offer presumptive evidence of previous contact of turtles with a given pathogen (Glosser et al., 1974), but do not determine the moment of the infection or if, and how, the agent affects these turtles (Grimm et al., 2015).

\subsection{Molecular diagnosis of Leptospira}

A total of 132 samples of stomach and cloacal contents were obtained from the sixty-six P. geoffroanus captured. Specific amplification of Leptospira spp. genomic material (331 bp) was observed in $16.67 \%(11 / 66)$ of the lavage samples (eight gastric and three cloacal) from P. geoffroanus.

Mitchell et al. (2015) also used molecular methods for detection of Leptospira spp. and found this pathogen in 70.6\% (24/34) of urine samples from wild $E$. blandingii. Other researchers used PCR techniques on kidney and liver fragments from necropsied snakes and found genetic material of Leptospira spp. in 6.3\% (1/16) of the kidney samples obtained from a wild Crotaphopeltis hotamboeia (Herald Snake) (Jobbins and Alexander, 2015); Leptospira spp. was also detected by PCR in kidney and liver samples of one $(1 / 1)$ wildlife Bothrops pauloensis (Jararaca-pintada), and in kidney samples of two (2/2) captive Bothrops moojeni (Brazilian lancehead) (Biscola et al., 2011).

\subsection{Microagglutination test versus molecular diagnosis}

All the results from the molecular diagnosis tests (PCR) of Leptospira spp. and the microagglutination test (MAT) were compiled in Table 1.
Table 1

Results of PCR and MAT for Leptospira spp. from wild Phrynops geoffroanus (Geoffroy's side-necked turtle) captured in the urban stream Córrego Cerradinho, Jaboticabal, SP, Brazil.

\begin{tabular}{llll}
\hline & \multicolumn{2}{l}{ PCR Results } & Totals \\
\cline { 2 - 3 } & Detected & Not detected & \\
\hline Reactive MAT Results & $n 5^{\mathrm{a}}$ & $n 25$ & $n 30$ \\
Non reactive MAT Results & $n 6^{\mathrm{b}}$ & $n 30$ & $n 36$ \\
Totals & $n 11$ & $n 55$ & $\mathbf{N ~ 6 6}$ \\
\hline
\end{tabular}

a Gastric ( $n$ 4) and cloacal ( $n$ 1) samples.

b Gastric ( $n$ 4) and cloacal ( $n 2$ ) samples.

Five $P$. geoffroanus $(7.57 \%, 5 / 66)$ were positive simultaneously by PCR for Leptospira spp. and MAT. The serovars detected in these specimens were Autumnalis (1:160), Copenhageni (1:80 and $1: 160)$ and Pyrogenes $(1: 20$ and $1: 160)$. Biscola et al. (2011) studied wildlife and captive snakes ( $n 3$ ), and described the concurrent detection of the genomic material of Leptospira spp. in kidney samples and antibodies against this bacterium in serum samples (serovar Hardjo prajtino 1:200 and 1:1600).

The presence of Leptospira spp. (detected by PCR in this study) stimulates the development of antibodies by the host (Abdulla and Karstad, 1962); however, this situation was observed only in $45.45 \%$ (5/11) of the samples. The other $54.54 \%$ (6/11) of the animals were positive by PCR but had non-reactive MAT results. Possibilities to why this occurred include: an inability of the host's immune system to respond (immunodeficiency); a lack of Leptospira spp. immunogenicity; or too brief contact between the agent and the host to produce antibodies.

On the other hand, the detection of antibodies (45.45\%; 30/66) did not coincide with the detection of the agent by PCR. In $83.33 \%$ $(25 / 30)$ of the animals, PCR did not detect leptospiral genetic material. These facts might suggest that these terrapins have had previous contact with the agent. By the way, there is not substantial knowledge regarding the cellular immune response and the antibody kinetics of $P$. geoffroanus infected by Leptospira spp.; neither about the period in which antibody titers remain detectable in this animal species; nor if the absence of the agent, at the moment of sample collection, denotes lack of current infection.

Considering PCR as gold standard diagnostic technique for detection of leptospires, we observed that MAT had low sensitivity $(45.45 \%)$ and specificity (54.54\%) in the present study. These results may have occurred owing to the small sample size (66 wild animals), or to the use of diluted material (gastric or cloacal lavage samples) for PCR instead of organ fragments (from kidneys or liver, for example).

Additionally, little is known about the pathogenicity of Leptospira spp. toward terrapins (Abdulla and Karstad, 1962; Mitchell et al., 2015) since these animals and this bacterium may have been coexisting for a long time in the aquatic environment (Andrews et al., 1965; Glosser et al., 1974). Have they coevolved? Some of these questions raised could be answered by experimentally infecting aquatic testudines with Leptospira spp.

\subsection{Testudines and Leptospira spp.: a public issue}

The presence of pathogenic Leptospira spp. in body fluids or tissues (Mérien et al., 1992) may lead to leptospiremia and leptospiruria (Abdulla and Karstad, 1962), with consequent dissemination of leptospires into aquatic ecosystems (Abdulla and Karstad, 1962; Mitchell et al., 2015). Terrapins may prove useful as sentinel species for the assessment of environmental contamination by Leptospira spp. (Grimm et al., 2015).

Considering that (1) Leptospira spp. is an important zoonotic agent (Silva et al., 2012), which survives in aquatic environment 
and use it as transmission way (Plank and Dean, 2000; OIE, 2016); (2) reptiles are continuously exposed to water-borne leptospires for a long time (Andrews et al., 1965; Glosser et al., 1974); and (3) evidence indicates that reptiles may spread leptospires to other reptiles, as confirmed by seroconversion and culture tests (Abdulla and Karstad, 1962), it has been suggested that reptiles may play a relevant role as reservoirs/host in leptospiral epidemiology (Abdulla and Karstad, 1962; Glosser et al., 1974; Jobbins and Alexander, 2015; Mitchell et al., 2015; Grimm et al., 2015).

The presence of wild animals in human-dominated landscapes allow overlapping between humans, wildlife (Jobbins and Alexander, 2015), and domestic animals (Grimm et al., 2015). This coexistence represents a health risk for susceptible animals (Abdulla and Karstad, 1962; Mitchell et al., 2015), including humans exposed during recreational activities and professionals working with terrapins (Grimm et al., 2015).

Further studies are required to determine the role of these animals in the epidemiology of Leptospira spp. (Grimm et al., 2015) and the risk of transmission to humans (Silva et al., 2009; LindtnerKnific et al., 2013; Grimm et al., 2015; Jobbins and Alexander, 2015).

\section{Conclusion}

The detection of Leptospira spp. DNA and anti-Leptospira antibodies in wild $P$. geoffroanus living in an urban environment indicates that these freshwater testudines host Leptospira spp. and eliminate them. This situation may represent a risk to public health, especially to people who use urban streams for fishing and recreational activities. Additionally, we described some Leptospira spp. serovars, not yet reported in testudines, detected here in $P$. geoffroanus.

\section{Acknowledgments}

J.P. O. received a scholarship from Coordination for the Improvement of Higher Education Personnel (CAPES). The authors are very thankful to Prof. Dr. Luis Antonio Mathias, Dr. Andressa de Souza Pollo, and Nivaldo Aparecido de Assis (FCAV/Unesp/Câmpus de Jaboticabal-SP, Brazil) for technical and laboratory support. The authors thank Prof. Dr. José Roberto Ferreira Alves Júnior (Instituto Federal Goiano - Campus Urutaí-GO, Brazil), Dr. Felipe Jorge da Silva, and Prof. Dr. Marcos Rogério André (FCAV/Unesp/Câmpus de Jaboticabal-SP, Brazil) for scientific collaboration.

\section{References}

Abdulla, P.K., Karstad, L., 1962. Experimental infections with Leptospira Pomona in snakes and turtles. Zoonoses Res. Lyceum Press 1 (16), 295-306.

Acha, P.N., Szyfres, B., 2001. Zoonosis y enfermedades transmisibles comunes al hombre y a los animales, 1., 3. ed. Organización Panamericana de la Salud, Washington, pp. 175-186 (Publicación Científica y Técnica, 580). Available at http://www.paho.org/hq/index.php?option=com_docman\&task=doc view\&gid=19161\&Itemid $=($ accessed 11.08.16)

Adler, B., Moctezuma, A.P., 2010. Leptospira and leptospirosis. Vet. Microbiol. 27 (3-4), 287-296, http://dx.doi.org/10.1016/j.vetmic.2009.03.012.

Andrews, R.D., Reilly, J.R., Ferris, D.H., Hanson, L.E., 1965. Leptospiral agglutinins in sera from southern Illinois herpetofauna. J. Wildl. Dis. Wildl. Dis. Assoc. Lawrence 1 (4), 55-59, http://dx.doi.org/10.7589/0090-3558-1.4.55.

Biscola, N.P., Fornazari, F., Saad, E., Richini-Pereira, V.B., Campagner, M.V., Langoni, H., Barraviera, B., Ferreira Junior, R.S., 2011. Serological investigation and pcr in detection of pathogenic leptospires in snakes. Pesquisa Vet. Bras. Rio de Janeiro 31 (9), 806-811, http://dx.doi.org/10.1590/S0100-736X2011000900013.
Borges, M.J., Galbiatti, J.A., Ferraudo, A.S., 2003. Monitoramento de qualidade hídrica e eficiência de interceptores de esgoto em cursos d'água urbanos da bacia hidrográfica do Córrego Jaboticabal. Revista Bras. de Recursos Hídricos Porto Alegre 8 (2), 161-171, http://dx.doi.org/10.21168/rbrh.v8n2 (p 161-171)

Esteves, F.M., Guerra-Neto, G., Girio, R.J.S., Silva-Vergara, M.L., Carvalho, A.C.F.B., 2005. Detecção de anticorpos para Leptospira spp. em animais e funcionários do zoológico municipal de Uberaba, MG. Arquivos do Inst. Biol. São Paulo 72 (3), 283-288, Available at http://200.144.6.109/docs/arq/V72_3/esteves.PDF (accessed 11.04.16)

Glosser, J.W., Sulzer, C.R., Eberhardt, M., Winkler, W.G., 1974. Cultural and serologic evidence of Leptospira interrogans serotype Tarassovi infection in turtles. J. Wildl. Dis. Wildl. Dis. Assoc. Lawrence 10 (4), 429-435, http://dx.doi. org/10.7589/0090-3558-10.4.429.

Grimm, K., Mitchell, M.A., Thompson, D., Maddox, C., 2015. Seroprevalence of Leptospira spp. in Blanding's turtles (Emydea blandingii) from DuPage County Illinois USA. J. Herpetol. Med. Surg. Lawrence 25 (1-2), 28-32, http://dx.doi. org/10.5818/1529-9651-25.1.28.

Jobbins, S.E., Alexander, K.A., 2015. Evidence of Leptospira sp. infection among a diversity of African wildlife species: beyond the usual suspects. Trans. R. Soc. Trop. Med. Hygiene 109 (5), 349-351, http://dx.doi.org/10.1093/trstmh/trv007.

Kuramae-Izioka, E.E., 1997. A rapid, easy and high yield protocol for total genomic DNA isolation of Colletotrichum gloeosporioides and Fusarium oxysporum. Revista UNIMAR 19 (3), 683-689 (accessed 12.09.16.) http://periodicos.uem. br/ojs/index.php/RevUNIMAR/article/view/4550/3101.

Lindtner-Knific, R., Vergles-Rataj, A., Vlahovic, K., Zrimsek, P., Dovc, A., 2013. Prevalence of antibodies against Leptospira sp. in snakes, lizards and turtles in Slovenia. Acta Vet. Scand. Lond. 55 (1), 65, http://dx.doi.org/10.1186/1751 0147-55-65.

Mérien, F., Amouriaux, P., Perolat, P., Baranton, G., Saint-Girons, I., 1992. Polymerase chain reaction for detection of Leptospira spp. in clinical samples. J. Clin. Microbiol. Washington 30 (9), 2219-2224 (PMCID: PMC265482).

Mitchell, M., Rockwell, K., Thompson, D., Maddox, C., 2015. Characterizing the role of Blanding's turtle in the epidemiology of Leptospira. In: 2nd International Conference on Avian, HeRpetological and Exotic Mammal Medicine, 2015, Paris, 2nd International Conference on Avian, heRpetological and Exotic mammal medicine Proceedings. Paris : EAAV, AEMV, ARAV and ECZM (pp. 339).

OIE., 2.1.12. Leptospirosis, 2016. Manual of Diagnostic Tests and Vaccines for Terrestrial Animals 2016: OIE Terrestrial manual 2014. World Organisation for Animal Health, vol.1 part 2, section 2.1., chap. 2.1.12, pp. 01-15. Available at http://www.oie.int/en/international-standard-setting/terrestrialmanual/access-online/(accessed 11.08.16).

Plank, R., Dean, D., 2000. Overview of the epidemiology, microbiology and pathogenesis of Leptospira spp. in humans. Microbes Infect. Paris 2 (1), 1265-1276, http://dx.doi.org/10.1016/S1286-4579(00)01280-6.

Rueda-Almonacid, J.V., Carr, J.L., Mittermeier, R.A., Rodríguez-Mahecha, J.V., Mast, R.B., Vogt, R.C., Rhodin, A.G.J., Ossa-Velásquez, J., Rueda, J.N., Mittermeier, C.G., 2007. Las tortugas y los cocodrilianos de los países andinos del trópico. Editorial Panamericana, Conservación Internacional. Bogotá, Colombia, pp. 194-198 (Serie de guías tropicales de campo, 6).

Silva, E.F., Seyffert, N., Cerqueira, G.M., Leihs, K.P., Athanazio, D.A., Valente, A.L.S., Dellagostin, O.A., Brod, C.S., 2009. Serum antileptospiral agglutinins in freshwater turtles from southern Brazil. Braz. J. Microbiol. São Paulo 40, 227-230, http://dx.doi.org/10.1590/S1517-83822009000200003.

Silva, C.S., Gírio, R.J.S., Guerra Neto, G., Brich, M., Santana, L.A.S., Amâncio, F.H., Mariani, J.R., Wessort, P.M.F., 2010. Anticorpos anti-Leptospira spp. em animais selvagens do zoológico municipal de Ribeirâo Preto, estado de Sâo Paulo, Brasil. Braz. J. Vet. Res. Anim. Sci. Sâo Paulo 47 (3), 237-242, Available at http://www.revistas.usp.br/bjvras/article/view/26862/28645 (accessed 06.05.16).

Silva, F.J., Conceição, W.L.F., Fagliari, J.J., Girio, R.J.S., Dias, R.A., Borba, M.R., Mathias, L.A., 2012. Prevalência e fatores de risco de leptospirose bovina no Estado do Maranhão. Pesquisa Veterinária Brasileira, Rio de Janeiro 32 (4), 303-312, Available at: http//www.scielo.br/pdf/pvb/v32n4/06. pdf (accessed 06.04.16).

Souza, F.L., Abe, A.S., 2000. Feeding ecology, density and biomass of the freshwater turtles Phrynops geoffroanus, inhabiting a polluted urban river in south-eastern Brazil. J. Zool. Soc. Lond. Lond. 252 (4), 437-446 (Available at htt://journals.cambridge.org/article_S0952836900000194 (accessed 06.04.16).

Souza, F.L., 2004. Uma revisão sobre padrões de atividade, reprodução e alimentação de cágados brasileiros (Testudines, Chelidae). Phyllomedusa Piracicaba 3 (1), 15-27, Available at http://www.phyllomedusa.esalq.usp.br/articles/volume3/number1/311527. pdf (accessed 06.04.16). 